\section{Validity of pre and post-term birth rates based on the date of last menstrual period compared to early obstetric ultrasonography}

\author{
Validade das taxas de nascimento pré e pós-termo \\ baseadas na data da última menstruação em \\ comparação com a ultrassonografia \\ obstétrica precoce
}

\author{
Validez de las tasas de nacimiento pre- y \\ pos-término, basadas en la fecha de la \\ última menstruación en comparación a \\ la ecografía obstétrica temprana
}

\author{
Maria Nilza Lima Medeiros 1 \\ Nádia Carenina Nunes Cavalcante 1 \\ Fabrício José Alencar Mesquita 1 \\ Rosângela Lucena Fernandes Batista 1 \\ Vanda Maria Ferreira Simões 1 \\ Ricardo de Carvalho Cavalli 2 \\ Viviane Cunha Cardoso 2 \\ Heloisa Bettiol 2 \\ Marco Antonio Barbieri 2 \\ Antônio Augusto Moura da Silva ${ }^{1}$
}

\section{Resumo}

\footnotetext{
1 Centro de Ciências da Saúde, Universidade Federal do Maranhão, São Luís, Brasil.

2 Faculdade de Medicina de Ribeirão Preto, Universidade de São Paulo, Ribeirão Preto, Brasil.

Correspondence A. A. M. Silva

Departamento de Saúde Pública, Centro de Ciências da Saúde, Universidade Federal do Maranhão. Rua Barão do Itapary 155 São Luís, MA 65020-070, Brasil.

aamouradasilva@gmail.com
}

\begin{abstract}
The aim of this study was to assess the validity of the last menstrual period (LMP) estimate in determining pre and post-term birth rates, in a prenatal cohort from two Brazilian cities, São Luís and Ribeirão Preto. Pregnant women with a single fetus and less than 20 weeks' gestation by obstetric ultrasonography who received prenatal care in 2010 and 2011 were included. The LMP was obtained on two occasions (at 22-25 weeks gestation and after birth). The sensitivity of LMP obtained prenatally to estimate the preterm birth rate was $65.6 \%$ in São Luís and 78.7\% in Ribeirão Preto and the positive predictive value was $57.3 \%$ in São Luís and $73.3 \%$ in Ribeirão Preto. LMP errors in identifying preterm birth were lower in the more developed city, Ribeirão Preto. The sensitivity and positive predictive value of LMP for the estimate of the post-term birth rate was very low and tended to overestimate it. LMP can be used with some errors to identify the preterm birth rate when obstetric ultrasonography is not available, but is not suitable for predicting post-term birth.
\end{abstract}

Premature Birth; Gestational Age; Prenatal Ultrasonography; Menstruation
O objetivo deste estudo foi avaliar a validade das estimativas das taxas de nascimento pré e póstermo baseadas na data da última menstruação (DUM), em uma coorte pré-natal de duas cidades brasileiras, Ribeirão Preto e São Luís. Foram incluídas gestantes de feto único com < 20 semanas de idade gestacional pela ultrassonografia obstétrica em 2010 e 2011. A DUM foi obtida de 22-25 semanas de idade gestacional e após o nascimento. A sensibilidade da DUM obtida no pré-natal para estimativa da taxa de nascimento pré-termo foi de 65,6\% em São Luís e de 78,7\% em Ribeirão Preto, e o valor preditivo positivo foi de 57,3\% em São Luís e de 73,3\% em Ribeirão Preto. Erros na DUM para identificação do nascimento pré-termo foram menores na cidade mais desenvolvida. A sensibilidade e o valor preditivo positivo da DUM para estimativa da taxa de nascimento pós-termo foram muito baixos, com tendência à sua superestimação. A DUM pode ser usada com algum erro para identificação do nascimento pré-termo quando a ultrassonografia obstétrica não estiver disponível, mas não tem validade para a estimativa do nascimento pós-termo.

Nascimento Prematuro; Idade Gestacional; Ultrassonografia Prenatal; Menstruação 


\section{Introduction}

The date of last menstrual period (LMP) has been the method most frequently used to estimate gestational age in epidemiological studies. However, its accuracy has been questioned because it assumes that women have regular menstrual cycles and that the self-reported information about LMP is precise 1,2 . It is influenced by retarded ovulation, bleeding at the beginning of pregnancy, use of an oral contraceptive after the perception of amenorrhea, short birth spacing and memory bias 3,4 . In addition, errors in gestational age estimate based on LMP are greater in populations of lower educational levels 5 .

On this basis, early obstetric ultrasonography performed during the first trimester of gestation has become the gold standard for the estimate of gestational age based on skull-rump length separately or in combination with last menstrual period 3. Due to the still low availability of obstetric ultrasonography in epidemiological studies, it is important to carry out studies for LMP validation. Studies have demonstrated that LMP tends to underestimate or overestimate the rate of preterm birth and to overestimate the rate of postterm birth 1,5,6. However, most of the available studies have been conducted in high-income countries 1,2 , with little information available for low and middle-income countries 5 , in which errors of gestational age classification based on LMP must be greater.

The objective of the present study was to assess the validity of the LMP estimate in determining pre and post-term birth rates, taking early obstetric ultrasonography as the gold standard, and to establish the agreement between the two methods.

\section{Material and methods}

A prospective cohort study was conducted in a non-probabilistic convenience sample of 1,400 pregnant women residing in Ribeirão Preto, São Paulo State, a more developed city, and 1,447 pregnant women residing in São Luís, Maranhão State, a less developed Brazilian city, from March 2010 to October 2011.

The inclusion criteria were being a pregnant woman, having performed an early obstetric ultrasonography with less than 20 weeks of gestation and carrying a single fetus. Skull-rump length $(<14$ weeks) and biparietal parameter (14 to 20 weeks) were the ultrasound parameters used to estimate gestational age ${ }^{3}$. The pregnant women were recruited at a health unit or in ultrasonography services in the two cities and in- vited to come to the Clinical Research Center in São Luís or to the Clinical Research Unit of the University Hospital, Ribeirão Preto Faculty of Medicine.

The women were interviewed from the 22nd to the 25th week of gestational age. The hospitals in the two cities were monitored daily for the identification of births belonging to the cohort. At the time of delivery, 66 women in São Luís (4.6\%) and 30 in Ribeirão Preto (2.1\%) were not located. Thus, 1,381 women were re-interviewed in São Luís and 1,370 in Ribeirão Preto, when they were asked again about date of last menstruation and date of delivery. Those sample sizes were above the minimum of 971 required to estimate a sensitivity or specificity around $50 \%$ with $10 \%$ absolute precision and $80 \%$ power, assuming a preterm birth rate of $10 \%$.

A birth was considered to be preterm when gestational age was $<37$ weeks and post-term when gestational age was $>42$ weeks. A total of 111 São Luís women and 157 Ribeirão Preto women were excluded because they did not know the last when asked during the prenatal care period (84 from São Luís and 144 from Ribeirão Preto) or because their gestational age was implausible, i.e. less than 20 weeks or 50 weeks or more (27 from São Luís and 13 from Ribeirão Preto). Regarding the last menstrual period obtained at delivery, 116 São Luís and 156 Ribeirão Preto women were excluded for the same reasons, i.e. 104 São Luís women and 151 Ribeirão Preto women because of missing gestational age and 12 São Luís women and 5 Ribeirão Preto women because of implausible gestational age.

Preterm and post-term birth rates were calculated according to gestational age estimates obtained during prenatal care and at birth based on LMP and obstetric ultrasonography. The OpenEpi software (Dean AG, Sullivan KM, Soe MM. OpenEpi: Open Source Epidemiologic Statistics for Public Health, http://www.OpenEpi. com) was used to calculate sensitivity, specificity, positive predictive value, negative predictive value and kappa coefficient to determine the agreement between the two methods. 95\% confidence intervals were also calculated for these estimates. Agreement was considered excellent when $>0.75$, intermediate from 0.40 to 0.75 and poor when $<0.40$.

The Ethics Research Committees of both centers approved the project and all mothers gave written informed consent. 


\section{Results}

The preterm birth rates determined by both the last menstrual period obtained during the prenatal period and the LMP obtained at delivery were usually higher than those obtained by obstetric ultrasonography in both cities. The same was observed for the post-term rates, which were considerably overestimated when calculated on the basis of LMP (Table 1).

Excellent agreement regarding preterm birth was observed between last menstrual period obtained during the prenatal period and LMP obtained at birth, both in São Luís (kappa coefficient $=0.78 ; \mathrm{p}<0.001$ ) and Ribeirão Preto (kappa coefficient $=0.91 ; \mathrm{p}<0.001)$.
The identification of preterm birth by prenatally determined LMP showed $65.6 \%$ sensitivity, $96 \%$ specificity, $57.3 \%$ positive predictive value and $97.2 \%$ negative predictive value compared to obstetric ultrasonography as the gold standard, with intermediate agreement between the two estimates (kappa coefficient $=0.58$ ) in São Luís. Higher values were observed in Ribeirão Preto = $78.7 \%$ sensitivity $96.8 \%$ specificity, $73.3 \%$ positive predictive value, $97.6 \%$ negative predictive value, and a kappa coefficient of 0.73. Similar values were obtained for LMP determined at birth for both cities (Table 2 ).

Table 1

Estimates of pre and post-term birth rates based on the date of last menstrual period (LMP) obtained during prenatal care, at birth and by obstetric ultrasonography. São Luís, Maranhão State and Ribeirão Preto, São Paulo State, Brazil, 2010/2011.

\begin{tabular}{|c|c|c|c|c|c|c|}
\hline \multirow[t]{2}{*}{ Estimates } & \multicolumn{2}{|c|}{$\begin{array}{l}\text { LMP obtained during prenatal } \\
\text { care }\end{array}$} & \multicolumn{2}{|c|}{ LMP obtained at birth } & \multicolumn{2}{|c|}{$\begin{array}{l}\text { Obstetric } \\
\text { ultrasonography }\end{array}$} \\
\hline & $n$ & $\%$ & $n$ & $\%$ & $\mathrm{n}$ & $\%$ \\
\hline \multicolumn{7}{|l|}{ Preterm birth } \\
\hline São Luís & 1,270 & 8.7 & 1,265 & 7.4 & 1,381 & 7.5 \\
\hline Ribeirão Preto & 1,213 & 10.8 & 1,214 & 11.1 & 1,370 & 9.7 \\
\hline \multicolumn{7}{|l|}{ Post-term birth } \\
\hline São Luís & 1,270 & 4.1 & 1,265 & 3.8 & 1,381 & 1.2 \\
\hline Ribeirão Preto & 1,213 & 6.2 & 1,214 & 5.3 & 1,370 & 0.3 \\
\hline
\end{tabular}

Table 2

Validity and agreement between estimates of preterm birth rate based on the date of last menstrual period (LMP) obtained during prenatal care and at birth and on early obstetric ultrasonography. São Luís, Maranhão State and Ribeirão Preto, São Paulo State, Brazil, 2010/2011.

\begin{tabular}{|c|c|c|c|c|}
\hline \multirow[t]{2}{*}{ City } & \multicolumn{2}{|c|}{ LMP obtained during prenatal care } & \multicolumn{2}{|c|}{ LMP obtained at birth } \\
\hline & Value & $95 \% \mathrm{Cl}$ & Value & $95 \% \mathrm{Cl}$ \\
\hline São Luís & $n=1,270$ & & $n=1,265$ & \\
\hline Sensitivity & 65.6 & $55.7-74.4$ & 63.0 & $52.8-72.2$ \\
\hline Specificity & 96.0 & $94.7-97.0$ & 97.0 & $95.9-97.9$ \\
\hline Positive predictive value & 57.3 & $47.9-66.1$ & 62.4 & $52.2-71.5$ \\
\hline Negative predictive value & 97.2 & $96.0-98.0$ & 97.1 & $96.0-98.0$ \\
\hline Kappa & 0.58 & $0.5-0.6$ & 0.6 & $0.5-0.7$ \\
\hline Ribeirão Preto & $n=1,213$ & & $n=1,214$ & \\
\hline Sensitivity & 78.7 & $70.6-85.0$ & 79.2 & $71.1-85.5$ \\
\hline Specificity & 96.8 & $95.6-97.7$ & 96.3 & $95.1-97.3$ \\
\hline Positive predictive value & 73.3 & $65.1-80.1$ & 70.4 & $62.2-77.4$ \\
\hline Negative predictive value & 97.6 & $96.5-98.4$ & 97.7 & $96.6-98.4$ \\
\hline Kappa & 0.73 & $0.67-0.79$ & 0.72 & $0.66-0.77$ \\
\hline
\end{tabular}

95\% Cl: 95\% confidence interval. 
Validity and agreement between estimates of post-term birth rate based at the time of last menstrual period (LMP) obtained during prenatal care, at birth and on early obstetric ultrasonography. São Luís, Maranhão State and Ribeirão Preto, São Paulo State, Brazil, 2010/2011.

\begin{tabular}{|c|c|c|c|c|}
\hline \multirow[t]{2}{*}{ City } & \multicolumn{2}{|c|}{ LMP obtained during prenatal care } & \multicolumn{2}{|c|}{ LMP obtained at birth } \\
\hline & Value & $95 \% \mathrm{Cl}$ & Value & $95 \% \mathrm{Cl}$ \\
\hline São Luís & $\mathrm{n}=1,270$ & & $\mathrm{n}=1,265$ & \\
\hline Sensitivity & 50.0 & $26.8-73.2$ & 41.7 & $19.3-68.1$ \\
\hline Specificity & 96.4 & $95.2-97.3$ & 96.6 & $95.4-97.4$ \\
\hline Positive predictive value & 13.5 & $6.7-25.3$ & 10.4 & $4.5-22.2$ \\
\hline Negative predictive value & 99.4 & $98.8-99.7$ & 99.4 & $98.8-99.7$ \\
\hline Kappa & 0.20 & $0.2-0.2$ & 0.15 & $0.1-0.2$ \\
\hline Ribeirão Preto & $\mathrm{n}=1,213$ & & $\mathrm{n}=1,214$ & \\
\hline Sensitivity & 33.3 & $6.1-79.2$ & 33.3 & $6.1-79.2$ \\
\hline Specificity & 93.8 & $92.3-95.0$ & 94.7 & $93.3-95.8$ \\
\hline Positive predictive value & 1.3 & $0.2-7.1$ & 1.5 & $0.3-8.2$ \\
\hline Negative predictive value & 99.8 & $92.1-94.9$ & 99.8 & $99.4-99.9$ \\
\hline Kappa & 0.02 & $0.01-0.04$ & 0.02 & $0.01-0.04$ \\
\hline
\end{tabular}

95\% $\mathrm{Cl}: 95 \%$ confidence interval.

For the identification of post-term birth, LMP obtained during the prenatal period showed $50 \%$ sensitivity, $96.4 \%$ specificity, $13.5 \%$ positive predictive value and $99.4 \%$ negative predictive value compared to obstetric ultrasonography, which showed $33.1 \%$ sensitivity, $93.8 \%$ specificity, $1.3 \%$ positive predictive value and $99.8 \%$ with poor agreementbetween estimates (kappacoefficient= 0.02). Similar values were obtained for LMP determined at birth for both cities (Table 3).

\section{Discussion}

The sensitivity of LMP obtained during the prenatal period compared to obstetric ultrasonography was $65.6 \%$ in São Luís and $78.7 \%$ in Ribeirão Preto, and positive predictive value was $57.3 \%$ in São Luís and 73.3\% in Ribeirão Preto, indicating that last menstrual period can be used with some error for the identification of preterm birth. However, last menstrual period should not be used for the identification of post-term birth since its sensitivity and positive predictive values were very low.

Although similar, and pointing in the same direction, the errors caused by the use of LMP for the identification of preterm birth were lower in the more developed city. Lower LMP sensitivity for the estimate of preterm birth in São Luís may have been due to socioeconomic differences, particularly with regard to the educational level of the women 2,5 , which is lower in this less developed city.

The estimated sensitivity and positive predictive value of LMP for the identification of preterm birth were similar to those observed in some studies conducted in Brazil 4,5 and in other places 1,2. In the Nascer no Brasil (Birth in Brazil) study conducted at the national level, regarding the estimate of preterm birth based on last menstrual period compared to early obstetric ultrasonography, $69.4 \%$ sensitivity was observed for pregnant women treated in the public sector and $72 \%$ sensitivity was observed for those treated in the private sector. The present results are also consistent with other Brazilian studies which demonstrated that the use of LMP overestimates the rate of preterm birth by about $10 \%$ to $34 \% 4,5$ while considerably underestimating the post-term birth rate 5 . However, a study conducted in Canada demonstrated that the use of LMP underestimates the preterm birth, in contrast to what was observed here 1 . Inconsistencies in LMP results for the estimate of preterm birth may be caused by different errors that may vary among populations and may produce under- or overestimates of the preterm birth rate. The occurrence of false-positive and false-negative results is a problem with the use of LMP in studies on risk factors for preterm birth.

A limitation of the present study was that it was based on a convenience sample of women predominantly using public health services. In 
this convenience sample, the social extremes of the population were under-represented, with the possibility that errors of gestational age classification were either greater (due to the lower participation of poorer users) or lower (due to the lower participation of wealthier users) than those presented here. In addition, since the objective of the study was not to estimate the preterm birth rate, we opted not to exclude extreme birth weight values according to gestational age, so that the validity of LMP could be assessed in more real situations. Another limitation is that different examiners performed obstetric ultrasonography. A strength of the study is the sample size, which included more than 2,000 women from two cities in two Brazilian regions, one more developed and the other less so.

\section{Resumen}

El objetivo de este estudio fue evaluar la validez de las estimaciones de las tasas de nacimiento pre- y pos-término, basadas en la fecha de la última menstruación (FUM), en una cohorte prenatal de dos ciudades de Brasil, São Luís y Ribeirão Preto. Se incluyeron mujeres embarazadas con un solo feto y<20 semanas de gestación por ecografía obstétrica en 2010 y 2011. La FUM se obtuvo en 22-25 semanas de gestación y después del nacimiento. La sensibilidad de la FUM, obtenida prenatalmente para estimar la tasa del parto prematuro, fue de un 65,6\% en São Luís y 78,7\% en Ribeirão Preto y el valor predictivo positivo fue un 57,3\% en São Luis y el 73,3\% en Ribeirão Preto. La sensibilidad y valor predictivo positivo de la FUM para la estimación de la tasa de nacimiento pos-término fueron muy bajos con tendencia a sobreestimarla. Se puede utilizar la FUM con algunos errores para identificar la tasa de parto prematuro cuando la ecografía obstétrica no está disponible, pero no es adecuada para predecir el parto pos-término.

Nacimiento Prematuro; Edad Gestacional;

Ultrasonografia Prenatal; Mestruación

\section{Conclusion}

Although the estimate of gestational age based on LMP represents a simple, easily available and low cost method widely used in epidemiological studies, it involves errors of classification for preterm birth and especially for post-term births. The estimate of gestational age based on LMP should be used with caution in epidemiological studies when obstetric ultrasonography is not available for the estimate of preterm birth rates. Its use is not recommended to estimate post-term birth rates. In any case, the preferred method for the evaluation of gestational age in epidemiological studies is obstetric ultrasonography alone or in combination with last menstrual period ${ }^{3}$. LMP should be used alone only when obstetric ultrasonography estimates of gestational age were not available.

\section{Contributors}

M. N. L. Medeiros analyzed the data, wrote the draft and the final version of the manuscript, review and approved the final version of the manuscript. N. C. N. Cavalcante and F. J. A. Mesquita performed the statistical analysis, analyzed the data, review and approved the final version of the manuscript. R. L. F. Batista and V. C. Cardoso cleaned and analyzed the data, review and approved the final version of the manuscript. V. M. F. Simões and R. C. Cavalli analyzed the data, review and approved the final version of the manuscript. H. Bettiol and M. A. Barbieri conceived the study, analyzed the data, review and approved the final version of the manuscript. A. A. M. Silva conceived the study, performed the statistical analysis, analyzed the data, review and approved the final version of the manuscript.

\section{Acknowledgments}

We thank the interviewers and the mothers who kindly agreed to participate in the study. 


\section{References}

1. Kramer MS, McLean FH, Boyd ME, Usher RH. The validity of gestational age estimation by menstrual dating in term, preterm, and postterm gestations. JAMA 1988; 260:3306-8.

2. Dietz PM, England LJ, Callaghan WM, Pearl M, Wier ML, Kharrazi M. A comparison of LMP-based and ultrasound-based estimates of gestational age using linked California livebirth and prenatal screening records. Paediatr Perinat Epidemiol 2007; 21 Suppl 2:62-71.

3. Butt K, Lim K; Society of Obstetricians and Gynaecologists of Canada. Determination of gestational age by ultrasound. J Obstet Gynaecol Can 2014; 36:171-83.

4. Pereira APE, Leal MC, Gama SGN, Domingues RMSM, Schilithz AOC, Bastos MH. Determinação da idade gestacional com base em informações do estudo Nascer no Brasil. Cad Saúde Pública 2014; 30 Suppl:S59-70.
5. Pereira AP, Dias MA, Bastos MH, da Gama SG, Leal MC. Determining gestational age for public health care users in Brazil: comparison of methods and algorithm creation. BMC Res Notes 2013; 6:60.

6. Hall ES, Folger AT, Kelly EA, Kamath-Rayne BD. Evaluation of gestational age estimate method on the calculation of preterm birth rates. Matern Child Health J 2014; 18:755-62.

Submitted on 12/Aug/2014

Final version resubmitted on 13/Jan/2015

Approved on 21/Jan/2015 